\title{
The Effectiveness of a Strategy Based on Action Research in Developing English Reading Comprehension Skills of Workers' University Students
}

\section{Dr. Elsayed Ahmed Mohammad Sadaka}

Assistant Lecturer of English Language Workers' University

\section{Abstract}

This pre-post experimental study aimed at
investigating the effectiveness of a strategy
based on Action Research in developing English reading comprehension skills of Workers' University students, Kafr ElSheikh branch. The participants consisted of 70 students chosen from 1st year Workers' University students, department of industrial affairs in the first semester 2018 - 2019. The researcher used the following instruments: a reading comprehension skills checklist, and a pre-posttest on reading comprehension skills. The results revealed that there are statistically significant differences at (0.05) between the mean scores of the experimental group students and those of the control group students in the posttest in English reading comprehension skills in favor of the experimental group. Furthermore, the results pointed out that there are statistically significant differences at (0.05) between the mean scores of the experimental group students in the pre and post-test of some English reading comprehension skills in favor of the post-test.

Key words: action research, English reading comprehension skills

\section{Introduction}

Language is the most important instrument of communication between members of any society on the one hand and different peoples from different cultures on the other. The study of foreign languages, especially 
English, has an important place in our age. Reading is one of the most important instruments of human knowledge. Syaveny (2017) confirmed that reading is not only seeing or reading what is written but also comprehending the contents of the reading, thus, the readers get the knowledge and information from the text. Behjat, Bagheri \& Yamini, (2012) stated that reading comprehension is regarded as the ability of perceiving a written text in order to understand its elements and contents. The main concept in reading skill is 'comprehension'. Both of students and teachers value reading comprehension greatly as it increases the process of language acquisition and helps students to read for different purposes. The most successful readers are those who use cognitive strategies to comprehend the text better.

Riahi \& Pourdana (2017) indicated that reading is considered as the most important language skill in our modern life since it helps people to learn new knowledge and experience the world everywhere at any time. Lin (2017) stated that English reading is regarded as one of the most essential language skills in universities where English is learned as a foreign language (EFL). In most situations, English written text (text books, journals and articles, online resources, and texts translated from other foreign languages, etc.) is a helpful medium for delivering worldwide and cuttingedge knowledge.

Through reading, man can find his way to thinking and affective development. Reading comprehension is viewed as a critical skill in the educational process. Reading comprehension skills facilitate students' understanding in all subject areas. Therefore, reading comprehension is urgently needed for all areas of study. 
Reading proficiency is regarded as the most fundamental skill critical to most, if not all, academic learning and success in school. In the United States, the ability to read proficiently is significantly related to how much a person can achieve in his or her personal and professional life (Block \& Israel, 2005, p. 2).

Ariffin (2004) confirmed that reading comprehension is beneficial to non-English speaking students, especially EFL students, as it helps them to use their previous knowledge in reading topics and subjects, demonstrate their feelings and ideas when they write, and tackle the problem of students who are asked to write in a way that is not found in their own culture. Moreover, Deutsch (2005) pointed out that reading comprehension skills inspires the pleasure and effectiveness of reading. Reading comprehension skills are very important in all the other subjects and in the personal and professional lives. He added that the tests that control advancement through elementary, middle and high school and which determine students' access to college are in large parts, a measure of reading comprehension skills. As well, Learning $\mathrm{Rx}$ Center (2010) affirmed that reading comprehension allows the student to interact with the text in a meaningful way. It is considered as the bridge from passive reading to active reading, from letters and words to characters and contexts. It is the vital connection to effective reading and opens the lifetime gate of reading for entertainment and enjoyment.

Duke and Pearson (2008) presented sixteen strategies that may be used by good readers. These strategies involve the construction, revising, and questioning of the meanings that they are making while reading. They viewed the topic of comprehension from 
the instructional side. They urged the importance of balance in comprehension instruction. Balance instruction entails 'specific comprehensive instruction' and a 'great deal of time' on task - reading, writing, and discussing. Some main points related to this balanced approach involved: lots of reading experiences, reading with a real purpose, vocabulary development opportunities, writing text for others to read, and the discussion of the read text.

Mohaidat (2018) asserted that reading comprehension has become a field of study for various educational and psych-educational researchers as they investigated all the factors that might hinder comprehension and the strategies that might contribute to its improvement. Mohaidat (2018) affirmed that reading comprehension is the ability to understand the meanings, rephrase ideas and concepts in terms of the previous knowledge that the individual acquired from reading texts.

Action Research is regarded as a powerful tool, as it not only sheds light on the complexities of the teaching process in day-to-day life, but it is considered also as the best way to make the policymakers aware of the difficulties of the irrelevant policies imposed upon teachers (Meyers and Rust ,2003, cited in Mohan, 2017). Moreover, Hassen (2016) indicated that action research is one of the different approaches of educational research methods.

Burns (2000) pointed out that action research is regarded as an essential tool for school and classroom investigation. He affirmed that the purposes of action research in education fall broadly into categories that reflect action research as: a way to solve problems in 
specific situations, a means of in-service training for the teachers to train them in new skills and methods, a means of devising innovatory approaches of teaching and learning, a means of enhancing the normally poor communications between the practicing teachers and the academic researchers, and a means of finding a preferable substitute to the more subjective, impressionistic approach to problem-solving in the classroom.

Concerning the role of action research in developing reading comprehension skills, Mustakim (2013) asserted that the use of action research had improved literal reading comprehension and interpretative reading comprehension. Luo (2013) pointed out that action research achieved a good improvement of reading ability with a result showing significant difference. Rahaman (2014) proved that action research is carried out to make a change of classroom activities. He added that action research enables learners to be more interactive and socialized in the classroom. Tamor (2017) confirmed the importance of using action research to develop reading difficulties of grade one pupils in Macatoc Elementary School.

\section{Statement of the Problem}

The problem of the study can be stated in that Workers' University students face some problems in English reading comprehension skills. Therefore, this research attempts to use action research to develop English reading comprehension skills of Workers' University students.

\section{Research Questions}

This research attempted to answer the following main question: 
How effective is the use of action research in developing English reading comprehension skills of Workers' University students?

This question is divided into other sub-questions, they are:

1) What are the reading comprehension skills needed to be developed for Workers' University students to comprehend the reading passage in their prescribed textbook?

2) To what extent is action research strategy effective in developing these reading comprehension skills?

\section{Research Hypotheses}

This research examined the following hypotheses:

3) There are statistically significant differences at (0.05) between the mean scores of the experimental group students and those of the control group students in the post-test in English reading comprehension skills in favor of the experimental group.

4) There are statistically significant differences at (0.05) between the mean scores of the experimental group students in the pre and post-test of some English reading comprehension skills in favor of the post-test.

\section{The Significance of the Research}

As for Students, action research can help develop students' reading comprehension skills in English. With respect to teachers, action research can help teachers implement new steps, activities, procedures, techniques, and organize effective teaching and learning environment concerning development of reading comprehension skills in English. Moreover, action research can help curriculum planners modify, enrich, and design programs that will improve reading comprehension skills in English. 


\section{The Objectives of the Research}

The main aim of the current research is to develop English reading comprehension skills using a strategy based on action research. This aim can be divided into the following objectives:

5) Identifying English reading comprehension skills needed to be developed for Workers' University students.

6) Identifying the effectiveness of action research in the development of English reading comprehension skills of Workers' University students.

\section{Delimitations of the Research}

The current research was limited to:

1. Workers' University - Kafr El-Sheikh branch, department of Industrial Affairs, year one during the academic year (2018-2019).

2. Action research based strategy.

3. Reading comprehension skills needed to be developed for Workers' University students to comprehend the reading passage in the prescribed textbook.

\section{Definition of Terms and Operational Definitions: Effectiveness:}

Effectiveness is defined as:

The UNESCO definition is: Vlãsceanu, L., Grünberg, L., \& Pârlea, D. (2007:54) defined effectiveness (educational) as "An output of specific review/analyses that measure (the quality of) the achievement of a specific educational goal or the degree to which a higher education institution can be expected to achieve specific requirements".

Productivity Commission (2013:6) defines effectiveness as "the extent to which stated objectives 
are met - the policy achieves what it intended to achieve".

The researcher will adopt the following operational definition: effectiveness is defined operationally as the degree of achievement or the amount of change that action research strategy makes on the development of reading comprehension skills and the translation skills in English among Workers' University students as a result of the semi-experimental treatments in the current research.

\section{Action Research:}

McNiff (2010: 8) defined it as: "a term which refers to a practical way of looking at your own work to check that it is as you would like it to be".

According to Wideman (2011:52) Action research is a "process of investigation based on development, execution, and evaluation of experiments".

Coghlan \& Brannick (2014: xix) defined action research as a "family of related approaches that integrate theory and action with a goal of addressing important organizational, community and social issues together with those who experience them".

Wang (2016:958) defined action research as "the combination and interaction of two modes of activityaction and research. The action is located within the ongoing social processes of particular societal context, and typically involves developments and interventions into those processes to bring about improvement and change. The research is located within the systematic observation and analysis of the developments and changes that eventuate in order to identify the underlying rationale for the action and to make further changes as required based on findings and outcomes". 
For Burns \& Westmacott (2018:16) action research is "a form of systematic inquiry that is usually appealing to teachers as it enables a focus on areas of their own practice that they consider worth investigating".

The researcher will adopt the following operational definition: action research is defined as an organized way to analyze an educational situation so as to contribute to the development of reading comprehension skills and text translation skills, and to enable students to solve their problems.

\section{Reading comprehension:}

Reading comprehension is defined as:

RAND Reading Study Group (2002:11) defines Reading comprehension as "the process of simultaneously extracting and constructing meaning through interaction and involvement with written language".

According to Van den Broek \& Espin, (2012:318) reading comprehension is "a complex interaction among automatic and strategic cognitive processes that enables the reader to create a mental representation of the text".

Lipka \& Siegel (2012:1873) defined Reading comprehension as: "a multi-dimensional process that includes the reader, the text, and factors associated with the activity of reading".

Barrot (2013:1) defined reading comprehension as "a process of simultaneously extraction and constructing meaning through interaction and involvement with written language".

Zhang, L. (2018:36) asserted that "reading comprehension is perceived as a constructive process in which the text, the reader, and the context interact". 
Mohaidat, M., (2018:32) defined reading comprehension as "a complex process associated with the brain. It requires linkage between the learning activities, the learner's experience and the learner's prior knowledge to form the meaning of a text".

The researcher will adopt the following operational definition: reading comprehension is defined: the ability of students of workers' university to find out the ideas and meanings included in the reading subjects.

\section{Method}

\section{Participants of the Research}

The participants of the research were 70 students. They were chosen from 1st year Workers' University students, Department of Industrial Affairs in the first semester 2018 - 2019. The students live in an exclusively Arabic-speaking community and have learned English as a foreign language. The students were randomly divided into two groups (experimental group and control group) according to the routine of the students affairs adopted by Workers' University (35 students for the experimental group and 35 students for the control group).

\section{The Research Instruments}

The researcher used the following instruments to achieve the purpose of the research:

- A reading comprehension skills checklist to identify the reading comprehension skills required to be developed for the students of Workers' University in English (prepared by the researcher).

- A pre/post test on reading comprehension skills to evaluate Workers' University students' reading comprehension skills. (prepared by the researcher). 


\section{Results of the Statistical Analysis:}

Verifying the First Hypothesis of the Research:

The first hypothesis states that: "There are statistically significant differences at $(0.05)$ between the mean scores of the experimental group students and those of the control group students in the post-test in English reading comprehension skills in favor of the experimental group".

In order to verify this hypothesis, the researcher compared the mean scores of the experimental group students and those of the control group students in reading comprehension skills as a whole in the posttest. In addition, the researcher used t-test for independent samples to find out if there were any statistically significant differences between the experimental and control groups after conducting the strategy.

Table 1: T-test Results of the Post-test for the Experimental and Control Groups in Overall Reading Comprehension Skills

\begin{tabular}{lllllll}
\hline Group & N. & Mean & S.D & $\begin{array}{l}\text { T- } \\
\text { Value }\end{array}$ & D.F & Sig. \\
\hline Control & $\mathbf{3 5}$ & $\mathbf{2 2 . 9 7 1 4}$ & $\mathbf{3 . 3 4 7 3 9}$ & $\mathbf{1 6 . 0 8 5}$ & $\mathbf{6 8}$ & sig. \\
Experimental & $\mathbf{3 5}$ & $\mathbf{4 1 . 2 2 8 6}$ & $\mathbf{5 . 8 2 1 2 9}$ & & & \\
\hline
\end{tabular}

In table (1), the t-value is (16.085) which means that there are statistically significant differences at (0.05) between the mean scores of the experimental group students and those of the control group students in the post-test in English reading comprehension skills in favor of the experimental group. This means that using a strategy based on action research is effective in developing some English reading comprehension skills of Workers' University students. Therefore, these results prove the first hypothesis of the study. 
Table 2: T-test Results of the Post-test for the Experimental and Control Groups in Each Reading Comprehension Skill

\begin{tabular}{|c|c|c|c|c|c|c|c|}
\hline Skills & Groups & $\mathbf{N}$. & Mean & S.D. & $T$ & D.F & Sig. \\
\hline $\begin{array}{l}\text { Suggesting a title } \\
\text { for the text }\end{array}$ & $\begin{array}{l}\text { Cont. } \\
\text { Exp. }\end{array}$ & $\begin{array}{l}35 \\
35\end{array}$ & $\begin{array}{l}1.57 \\
3.37\end{array}$ & $\begin{array}{l}0.815 \\
1.190\end{array}$ & 7.383 & 68 & Sig. \\
\hline $\begin{array}{l}\text { Identifying the main } \\
\text { idea of the text }\end{array}$ & $\begin{array}{l}\text { Cont. } \\
\text { Exp. }\end{array}$ & $\begin{array}{l}35 \\
35\end{array}$ & $\begin{array}{l}2.31 \\
4.40\end{array}$ & $\begin{array}{l}0.867 \\
1.218\end{array}$ & 8.256 & 68 & Sig. \\
\hline $\begin{array}{l}\text { Identifying the main } \\
\text { points of the text }\end{array}$ & $\begin{array}{l}\text { Cont. } \\
\text { Exp. }\end{array}$ & $\begin{array}{l}35 \\
35\end{array}$ & $\begin{array}{l}2.80 \\
4.57\end{array}$ & $\begin{array}{l}0.473 \\
0.739\end{array}$ & 11.945 & 68 & Sig. \\
\hline $\begin{array}{l}\text { Guessing the } \\
\text { meaning of new } \\
\text { words }\end{array}$ & $\begin{array}{l}\text { Cont. } \\
\text { Exp. }\end{array}$ & $\begin{array}{l}35 \\
35\end{array}$ & $\begin{array}{l}1.63 \\
3.31\end{array}$ & $\begin{array}{l}0.910 \\
1.762\end{array}$ & 5.029 & 68 & Sig. \\
\hline $\begin{array}{l}\text { Reading for specific } \\
\text { information }\end{array}$ & $\begin{array}{l}\text { Cont. } \\
\text { Exp. }\end{array}$ & $\begin{array}{l}35 \\
35\end{array}$ & $\begin{array}{l}1.86 \\
4.03\end{array}$ & $\begin{array}{l}0.944 \\
1.465\end{array}$ & 7.372 & 68 & Sig. \\
\hline $\begin{array}{l}\text { Distinguishing the } \\
\text { main ideas from } \\
\text { supporting details }\end{array}$ & $\begin{array}{l}\text { Cont. } \\
\text { Exp. }\end{array}$ & $\begin{array}{l}35 \\
35\end{array}$ & $\begin{array}{l}2.63 \\
4.40\end{array}$ & $\begin{array}{l}0.690 \\
0.914\end{array}$ & 9.153 & 68 & Sig. \\
\hline Making inferences & $\begin{array}{l}\text { Cont. } \\
\text { Exp. }\end{array}$ & $\begin{array}{l}35 \\
35\end{array}$ & $\begin{array}{l}2.46 \\
3.97\end{array}$ & $\begin{array}{l}0.817 \\
1.361\end{array}$ & 5.644 & 68 & Sig. \\
\hline $\begin{array}{c}\text { Distinguishing } \\
\text { between facts and } \\
\text { opinions }\end{array}$ & $\begin{array}{l}\text { Cont. } \\
\text { Exp. }\end{array}$ & $\begin{array}{l}35 \\
35\end{array}$ & $\begin{array}{l}2.49 \\
4.23\end{array}$ & $\begin{array}{l}0.742 \\
1.114\end{array}$ & 7.703 & 68 & Sig. \\
\hline $\begin{array}{c}\text { Summarizing the } \\
\text { text }\end{array}$ & $\begin{array}{l}\text { Cont. } \\
\text { Exp. }\end{array}$ & $\begin{array}{l}35 \\
35\end{array}$ & $\begin{array}{l}2.51 \\
4.31\end{array}$ & $\begin{array}{l}0.818 \\
1.207\end{array}$ & 7.303 & 68 & Sig. \\
\hline $\begin{array}{l}\text { Drawing } \\
\text { conclusions }\end{array}$ & $\begin{array}{l}\text { Cont. } \\
\text { Exp. }\end{array}$ & $\begin{array}{l}35 \\
35\end{array}$ & $\begin{array}{l}2.71 \\
4.63\end{array}$ & $\begin{array}{l}0.750 \\
0.490\end{array}$ & 12.635 & 68 & Sig. \\
\hline
\end{tabular}

Table (2) shows that there are statistically significant differences between the mean scores of the experimental group students and those of the control group students in the post-test in favor of the experimental group in the skill of "Suggesting a title for the text", where "t" value is (7.383). Also, it indicates 
that there are statistically significant differences between the mean scores of the experimental group students and those of the control group students in the post-test in favor of the experimental group in the skill of "Identifying the main idea of the text", where " $t$ " value is (8.256). In addition, it indicates that there are statistically significant differences between the mean scores of the experimental group students and those of the control group students in the post-test in favor of the experimental group in the skill of "Identifying the main points of the text", where "t" value is (11.945). Likewise, it demonstrates that there are statistically significant differences between the mean scores of the experimental group students and those of the control group students in the post-test in favor of the experimental group in the skill of "Guessing the meaning of new words", where "t" value is (5.029). Furthermore, it illustrates that there are statistically significant differences between the mean scores of the experimental group students and those of the control group students in the post-test in favor of the experimental group in the skill of "Reading for specific information", where "t" value is (7.327).

Moreover, it points out that that there are statistically significant differences between the mean scores of the experimental group students and those of the control group students in the post-test in favor of the experimental group in the skill of "Distinguishing the main ideas from supporting details", where "t" value is (9.153). As well, it shows that there are statistically significant differences between the mean scores of the experimental group students and those of the control group students in the post-test in favor of the experimental group in the skill of "Making inferences", 
where " $t$ " value is (5.644). Also, it indicates that there are statistically significant differences between the mean scores of the experimental group students and those of the control group students in the post-test in favor of the experimental group in the skill of "Distinguishing between facts and opinions", where " $t$ " value is (7.703). In addition, it indicates that there are statistically significant differences between the mean scores of the experimental group students and those of the control group students in the post-test in favor of the experimental group in the skill of "Summarizing the text", where "t" value is (7.303). Likewise, it demonstrates that there are statistically significant differences between the mean scores of the experimental group students and those of the control group students in the post-test in favor of the experimental group in the skill of "Drawing conclusions", where " $t$ " value is (12.635).

\section{Verifying the Second Hypothesis of the Research:}

The second hypothesis stated that: "There are statistically significant differences at $(0.05)$ between the mean scores of the experimental group students in the pre-test and post-test of some English reading comprehension skills in favor of the post-test".

In order to verify this hypothesis, the researcher compared the mean scores of the experimental group students in both the pre-test and the post-test in overall reading comprehension skills. As well, the researcher used paired samples t-test to find out if there were any statistically significant differences between mean scores of the experimental group students in the pretest and the post-test of some English reading comprehension skills after conducting the strategy. 
Table 3: T-test Results of the Pre-test and the Post-test for the Experimental Group in Overall Reading Comprehension Skills

\begin{tabular}{llrrrrr}
\hline Group & N. & Mean & \multicolumn{1}{c}{ S.D } & T-Value & D.F & Sig. \\
\hline Pre-test & 35 & 19.49 & $\mathbf{3 . 0 4 3}$ & & & \\
Post-test & 35 & $\mathbf{3 7 . 4 0}$ & $\mathbf{7 . 4 0 5}$ & $\mathbf{1 2 . 1 8 8}$ & 34 & sig. \\
\hline
\end{tabular}

In table (3), the t-value is (12.188) which means that there are statistically significant differences at (0.05) between the mean scores of the experimental group students in the pre-test and post-test of some English reading comprehension skills in favor of the post-test. This means that using a strategy based on action research is effective in developing some reading comprehension skills of Workers' University students in favor of the post-test. Therefore, these results prove the second hypothesis of the study.

Table (4) shows that there are statistically significant differences between the mean scores of the experimental group students in the pre-test and the post-test in favor of the post-test in the skill of "Suggesting a title for the text", where "t" value is (10.178). Also, it indicates that there are statistically significant differences between the mean scores of the experimental group students in the pre-test and the post-test in favor of the post-test in the skill of "Identifying the main idea of the text", where "t" value is (10.712). In addition, it indicates that there are statistically significant differences between the mean scores of the experimental group students in the pretest and the post-test in favor of the post-test in the skill of "Identifying the main points of the text", where " $t$ " value is (11.918). Likewise, it demonstrates that there are statistically significant differences between the mean scores of the experimental group students in the pre-test and the post-test in favor of the post-test in the 
skill of "Guessing the meaning of new words", where " $t$ " value is (6.906). Furthermore, it illustrates that there are statistically significant differences between the mean scores of the experimental group students in the pre-test and the post-test in favor of the post-test in the skill of "Reading for specific information", where " $t$ " value is (7.842).

Table 4: T-test Results of the Pre-test and the Post-test for the Experimental Group in Each Reading Comprehension Skill

\begin{tabular}{|c|c|c|c|c|c|c|c|}
\hline Skills & Groups & N. & Mean & S.D. & $\mathbf{T}$ & D.F & Sig. \\
\hline $\begin{array}{c}\text { Suggesting a title for } \\
\text { the text }\end{array}$ & $\begin{array}{l}\text { Pretest } \\
\text { Posttest }\end{array}$ & $\begin{array}{l}35 \\
35\end{array}$ & $\begin{array}{l}1.17 \\
3.37\end{array}$ & $\begin{array}{l}0.382 \\
1.190\end{array}$ & 10.178 & 34 & Sig. \\
\hline $\begin{array}{l}\text { Identifying the main } \\
\text { idea of the text }\end{array}$ & $\begin{array}{l}\text { Pretest } \\
\text { Posttest }\end{array}$ & $\begin{array}{l}35 \\
35\end{array}$ & $\begin{array}{l}1.83 \\
4.40\end{array}$ & $\begin{array}{l}0.747 \\
1.218\end{array}$ & 10.712 & 34 & Sig. \\
\hline $\begin{array}{l}\text { Identifying the main } \\
\text { points of the text }\end{array}$ & $\begin{array}{l}\text { Pretest } \\
\text { Posttest }\end{array}$ & $\begin{array}{l}35 \\
35\end{array}$ & $\begin{array}{l}2.31 \\
4.57\end{array}$ & $\begin{array}{l}0.676 \\
0.739\end{array}$ & 11.918 & 34 & Sig. \\
\hline $\begin{array}{l}\text { Guessing the } \\
\text { meaning of new } \\
\text { words }\end{array}$ & $\begin{array}{l}\text { Pretest } \\
\text { Posttest }\end{array}$ & $\begin{array}{l}35 \\
35\end{array}$ & $\begin{array}{l}1.20 \\
3.31\end{array}$ & $\begin{array}{l}0.406 \\
1.762\end{array}$ & 6.906 & 34 & Sig. \\
\hline $\begin{array}{l}\text { Reading for specific } \\
\text { information }\end{array}$ & $\begin{array}{l}\text { Pretest } \\
\text { Posttest }\end{array}$ & $\begin{array}{l}35 \\
35\end{array}$ & $\begin{array}{l}1.97 \\
4.03\end{array}$ & $\begin{array}{l}0.923 \\
1.465\end{array}$ & 7.842 & 34 & Sig. \\
\hline $\begin{array}{l}\text { Distinguishing the } \\
\text { main ideas from } \\
\text { supporting details }\end{array}$ & $\begin{array}{l}\text { Pretest } \\
\text { Posttest }\end{array}$ & $\begin{array}{l}35 \\
35\end{array}$ & $\begin{array}{l}2.11 \\
4.40\end{array}$ & $\begin{array}{l}0.758 \\
0.914\end{array}$ & 12.293 & 34 & Sig. \\
\hline Making inferences & $\begin{array}{l}\text { Pretest } \\
\text { Posttest }\end{array}$ & $\begin{array}{l}35 \\
35\end{array}$ & $\begin{array}{l}2.09 \\
3.97\end{array}$ & $\begin{array}{l}0.818 \\
1.361\end{array}$ & 8.160 & 34 & Sig. \\
\hline $\begin{array}{c}\text { Distinguishing } \\
\text { between facts and } \\
\text { opinions }\end{array}$ & $\begin{array}{l}\text { Pretest } \\
\text { Posttest }\end{array}$ & $\begin{array}{l}35 \\
35\end{array}$ & $\begin{array}{l}2.63 \\
4.23\end{array}$ & $\begin{array}{l}0.690 \\
1.114\end{array}$ & 9.697 & 34 & Sig. \\
\hline $\begin{array}{c}\text { Summarizing the } \\
\text { text }\end{array}$ & $\begin{array}{l}\text { Pretest } \\
\text { Posttest }\end{array}$ & $\begin{array}{l}35 \\
35\end{array}$ & $\begin{array}{l}1.94 \\
4.31\end{array}$ & $\begin{array}{l}0.725 \\
1.207\end{array}$ & 10.375 & 34 & Sig. \\
\hline Drawing conclusions & $\begin{array}{l}\text { Pretest } \\
\text { Posttest }\end{array}$ & $\begin{array}{l}35 \\
35\end{array}$ & $\begin{array}{l}2.23 \\
4.63\end{array}$ & $\begin{array}{l}0.808 \\
0.490\end{array}$ & 16.671 & 34 & Sig. \\
\hline
\end{tabular}

Moreover, it points out that that there are statistically significant differences between the mean scores of the experimental group students in the pre-test and the 
post-test in favor of the post-test in the skill of "Distinguishing the main ideas from supporting details", where " $t$ " value is (12.293). As well, it shows that there are statistically significant differences between the mean scores of the experimental group students in the pre-test and the post-test in favor of the post-test in the skill of "Making inferences", where " $t$ " value is (8.160). In addition, it indicates that there are statistically significant differences between the mean scores of the experimental group students in the pretest and the post-test in favor of the post-test in the skill of "Distinguishing between facts and opinions", where " $\mathrm{t}$ " value is (9.697). In addition, it indicates that there are statistically significant differences between the mean scores of the experimental group students in the pre-test and the post-test in favor of the post-test in the skill of "Summarizing the text", where "t" value is (10.375). Likewise, it demonstrates that there are statistically significant differences between the mean scores of the experimental group students in the pretest and the post-test in favor of the post-test in the skill of "Drawing conclusions", where "t" value is (16.671).

From the previous results, it became clear that there are statistically significant differences between the mean scores of the experimental group students in the pretest and post-test of some English reading comprehension skills in favor of the post-test. Moreover, the results reveal that the proposed educational strategy has improved English reading comprehension skills of the participants, where the experimental group's performance in the posttest was better than that in the pre-test; consequently, the second hypothesis is approved. 


\section{Conclusions}

With reference to the results mentioned above, it was concluded that the present study provided evidence regarding the positive effectiveness of Action Research strategy on developing English reading comprehension skills of Workers' University as follows:

- The proposed educational strategy (based on Action Research) was effective in developing the reading comprehension skills (Suggest a title for the text, Identifying the main idea of the text, Identifying the main points of the text, Guessing the meaning of new words, Reading for specific information, Distinguishing the main ideas from supporting details, Making inferences, Distinguishing between facts and opinions, Summarizing the text, and Drawing conclusions).

- The experimental group students achieved higher levels of performance on the post-test than in the pre-test in reading comprehension part that indicated the effectiveness of action research strategy.

- The current study showed that the experimental group students who were taught through using the suggested action research strategy were better than the control group students who were taught using the traditional method. The experimental group students achieved higher levels of performance because those students were provided with the opportunity to learn the content of the strategy using different steps and activities included in this strategy.

\section{Recommendations}

With respect to the results of the research, the following recommendations are suggested: 
1. Workers University should train TEFL instructor with respect to the use of Action Research in order to help their students to comprehend reading passages efficiently.

2. Using the suggested strategy (based on Action Research) as a compulsory course for training all the students of Workers' University on reading comprehension skills.

3. TEFL instructors should hold workshops to share their experience and views regarding the use of Acion Research in their classrooms.

4. Course designers should consider the inclusion of Action Research strategy when developing TEFL courses.

5. Planning for reading comprehension training programs giving priority to practice using Action Research.

6. Instructors ought to teach English in a communicative based method using Action Research. They should use authentic situations to enable their students to practice the use of English and then be able to communicate and write effectively.

7. Students should be exposed to the English language more through reading and writing.

8. Workers' University should give English instructors continuous training concerning new strategies and techniques of teaching English language.

\section{References}

- Ariffin, S. (2006). Culture in EFL Teaching: Issues and solutions. TESL Working Paper Series, 4(1), 75-78.

- Barrot, J. (2013). Revising the Role of Linguistic Complexity in ESL

- Reading Comprehension. 3L: The Southeast Asian Journal of English Language Studies, 19(1), 5-18.

- Behjat, F., Yamini, M., \& Bagheri, M. S. (2012). Blended Learning: A Ubiquitous Learning Environment for Reading Comprehension. International Journal of English Linguistics, 2(1), 97-105. 
- Block, C., \& Israel, S. (2005). Reading first and beyond: The complete Guide for teachers and literacy coaches. Thousand Oaks, CA: Corwin Press.

- Burns, R.B. (2000). Introduction to research methods, 4th ed, SAGE Publications, London.

- Burns, A. \& Westmacott, A. (2018). Teacher to Researcher: Reflections on a New Action Research Program for University EFL Teachers. Profile: Issues Teach. Prof. Dev., 20(1), 15-23. Retrieved on 8 May 2018 from https://doi.org/10.15446/ profile. v20n1.66236

- Coghlan, D., \& Brannick, T. (2014). Doing action research in your own organization. Thousand Oaks, CA: Sage Publishing.

- Deutsch, N. (2005).ESL/EFL Students Lack the Skills to Cope with Reading comprehension tests in Grade G, Unpublished M.A. Dissertation, University of Phonix, USA.

- Duke, N. K., \& Pearson, P. D. (2008). Effective Practices for Developing Reading Comprehension. Journal of Education, 189(1/2), 107-122.

- Hassen, R. (2016). Female Teachers' Professional Development through Action Research Practice. Journal of Education and Practice, 7(22), 6-18. ISSN 2222-1735 (Paper), ISSN 2222-288X (Online)

- Learning Rx Center. (2010). Reading Comprehension Skills. Retrieved on 12 January 2017 from: (http:// www.learningrx. com/ reading-comprehension-skills.html).

- Lin, L. (2017). Impacts of the Problem-based Learning Pedagogy on English Learners' Reading Comprehension, Strategy Use, and Active Learning Attitudes. Journal of Education and Training Studies, 5(6), 109-125. DOI:10.11114/jets.v5i6.2320

- Lipka, O. \& Siegel, L. (2012). The Development of Reading Comprehension Skills in Children Learning English as a Second Language. Reading \& Writing: An Interdisciplinary Journal, 25(8), 1873-1898.

- Luo, J. (2013). An Action Research on Improvement of Reading Comprehension of CET4. English Language Teaching, 6(4), 89-96, Canadian Center of Science and Education.

- McNiff, J. (2010). Action Research for Professional Development:

- Concise Advice for New Action Researchers, Teaching Development, the University of Waikato, New Zealand.

- Meyers, E., \& Rust, F. (Eds.). (2003). Taking Action with Teacher Research. Portsmouth, NH: Heinemann. 
- Mohaidat, M., (2018). The Impact of Electronic Mind Maps on Students' Reading Comprehension. English Language Teaching, 11(4), 32-42.

- Mohan, M. (2017). Book Review: Taking Action with Teacher Research by Meyers and Rust. i.e.: Inquiry in Education, 9(1), Article 5. Retrieved from: http://digitalcommons.nl.edu/ie/ vol9/iss $1 / 5$

- Mustakim, I. (2013). Improving the Students' Reading Comprehension through "TELLS" Strategy at the First Year Students of SMA Muhammadiyah 9 Perumnas Makassar. Exposure Journal, 2(1), 30-47.

- Productivity Commission (2013). On Efficiency and Effectiveness: Some Definitions, Staff Research Note, Canberra.

- Rahaman, A. (2014). Reading Comprehension through Group Work

- Activities in an EFL Classroom: An Action Research Report. Working Papers on Culture. Education and Human Development, 10(2), 1-8. Retrieved from: http://www.uam.es/otros/ptcedh/ 2014v10_pdf/v10n2eng.pdf

- RAND Reading Study Group. (2002). Reading for understanding: Toward An R\&D Program in Reading Comprehension. Santa Monica, CA: RAND Corporation.

- Riahi, Z. \& Pourdana, N. (2017). Effective Reading Comprehension in EFL Contexts: Individual and Collaborative Concept Mapping Strategies. Advances in Language and Literary Studies, 8(1), 5159. Doi:10.7575/aiac.alls.v.8n.1p.51

- Syaveny, N. (2017). Teaching Reading Comprehension by Using Directed Activities Related to Text (DRTA) for the Students. Journal KATA: 1(2), 153-158.

- Tamor, K. (2017). The Reading Difficulties of Grade One Pupils in Macatoc Elementary School, School Year 2016-2017: An Action Research: Action Research in Reading, Department of Education, Philippines. DOI: 10.13140/RG.2.2.15962.03523.

- Van den Broek, P., \& Espin, C. A. (2012). Connecting Cognitive Theory and Assessment: Measuring Individual Differences in Reading Comprehension. School Psychology Review, 41(3), 315325.

- Vlãsceanu, L., Grünberg, L., and Pârlea, D. (2007). Quality Assurance and Accreditation: A Glossary of Basic Terms and Definitions (Bucharest, UNESCO-CEPES) Revised and updated edition. ISBN 92-9069-186-7. Retrieved on 1 January 2019 from: http:// unesdoc.unesco.org/images/0013/001346/134621e.pdf 
- Wang, W. (2016). Peer Feedback in Chinese College English Writing Class: Using Action Research to Promote Students' English Writing. Journal of Language Teaching and Research, 7(5), 958-966. DOI: http://dx.doi.org/10.17507/jltr.0705.17

- Wideman, R. (2011). Empowering Teachers and Schools to Play Their Key Role in Improving Education. Canadian Journal of Action Research, 12(3), 47-59.

- Zhang, L. (2018). Metacognitive and Cognitive Strategy Use in Reading Comprehension: A Structural Equation Modelling Approach. Springer Nature Singapore Pte Ltd, Singapore. 